\title{
Different III-V semiconductor nanowires with quantum dots on silicon: growth by molecular-beam epitaxy and properties \\ Rodion R. Reznik ${ }^{\circledR}$, Konstantin P. Kotlyar ${ }^{2}$, Igor V. Shtrom ${ }^{3}$, Yuriy B. Samsonenko ${ }^{4}$, Artem I. Khrebtov 5 , George E. Cirlin6
}

\author{
1,6 ITMO University, Saint Petersburg, 197101, Russian Federation \\ 2,3 St. Petersburg State University, Saint Petersburg, 199034, Russian Federation \\ 4,5,6 Alferov University, Saint Petersburg, 194021, Russian Federation \\ 4,6 Institute for Analytical Instrumentation of the Russian Academy of Sciences, Saint Petersburg, 190103, Russian \\ Federation \\ 1 moment92@mail.ru ${ }^{\bowtie}$,htps://orcid.org/0000-0003-1420-7515 \\ 2 konstantin21kt@gmail.com, https://orcid.org/0000-0002-0305-0156 \\ 3 igorstrohm@mail.ru, https://orcid.org/0000-0001-8912-2570 \\ 4 samsonenko@beam.ioffe.ru, https://orcid.org/0000-0002-7119-3925 \\ 5 khrebtovart@mail.ru, https://orcid.org/0000-0001-5515-323X \\ 6 george.cirlin@mail.ru, https://orcid.org/0000-0003-0476-3630
}

\section{Abstract}

Recently, III-V semiconductor nanostructures of reduced dimension attract more and more interest of researchers for the new generation devices creation. Combinations of nanostructures with different dimensions are of special interest, among them, for example, quantum dots in the body of nanowires. Such quantum dots' size and location control is strictly determined by the growth parameters. As a result of effective relaxation of mechanical stresses on the lateral faces of nanowires, the integration of hybrid nanostructures with silicon technology is possible. In this work, we have demonstrated the possibility of GaP nanowires with GaAs quantum dots and $\mathrm{AlGaP}$ nanowires with InGaP quantum dots growth on silicon by molecular-beam epitaxy. The physical properties of the selected nanowires have been investigated. Growth experiments were performed using Riber Compact 21 setup, which is equipped, in addition to the growth chamber, with a vacuum-aligned chamber for gold deposition (metallization chamber). The morphological properties of the obtained nanostructures were studied by scanning electron microscopy. The optical properties of the nanostructures were investigated by the photoluminescence method. The analyses of morphological properties showed that GaP nanowires with GaAs quantum dots were formed predominantly in the $<111>$ direction, in contrast to AlGaP nanowires with InGaP quantum dots, which in some cases changed the growth direction. The reason for the change in the direction of growth of nanowires may be the participation of indium in the growth process. With a sufficient content of indium in the gold catalyst droplet, such mixed droplet can etch the facets at the top of the nanowires, thereby descending to the side of the nanowires and changing the direction of nanowires growth. The studies of the optical properties of the grown nanostructures showed that the photoluminescence signal from InGaP quantum dots in $\mathrm{AlGaP}$ nanowires is observed at a temperature of $-263{ }^{\circ} \mathrm{C}$ with a peak maximum of around $550 \mathrm{~nm}$. Thus, the synthesized nanostructures are promising for optoelectronic applications, in particular, for creating sources of single-photons.

\section{Keywords}

semiconductors, III-V, nanowires, quantum dots, silicon, morphology, photoluminescence

\section{Acknowledgements}

The samples were grown under support of Ministry of Science and Higher Education of the Russian Federation, research project No. 2019-1442. Morphological and optical properties measurements were done under support of Russian Foundation for Basic Research (RFBR) (project No 18-02-40006 mega).

For citation: Reznik R.R., Kotlyar K.P., Shtrom I.V., Samsonenko Yu.B., Khrebtov A.I., Cirlin G.E. Different III-V semiconductor nanowires with quantum dots on silicon: growth by molecular-beam epitaxy and properties. Scientific and Technical Journal of Information Technologies, Mechanics and Optics, 2021, vol. 21, no. 6, pp. 866-871. doi: 10.17586/2226-1494-2021-21-6-866-871 
УДК 537.311 .322

\title{
Синтез методом молекулярно-пучковой эпитаксии и свойства нитевидных нанокристаллов с квантовыми точками на основе соединений III-V групп на поверхности кремния
}

\author{
Родион Романович Резник $1 \bowtie$, Константин Павлович Котляр², \\ Игорь Викторович Штром 3 , Юрий Борисович Самсоненко 4 , \\ Артём Игоревич Хребтов 5 , Георгий Эрнстович Цырлин 6
}

1,6 Университет ИТМО, Санкт-Петербург, 197101, Российская Федерация

2,3 Санкт-Петербургский государственный университет, Санкт-Петербург, 199034, Российская Федерация

4,5,6 Санкт-Петербургский национально-исследовательский академический университет имени Ж.И. Алфёрова РАН, Санкт-Петербург, 194021, Российская Федерация

4,6 Институт аналитического приборостроения РАН, Санкт-Петербург, 190103, Российская Федерация

1 moment92@mail.ru ${ }^{\circledR}$, https://orcid.org/0000-0003-1420-7515

2 konstantin21kt@gmail.com, https://orcid.org/0000-0002-0305-0156

3 igorstrohm@mail.ru, https://orcid.org/0000-0001-8912-2570

4 samsonenko@beam.ioffe.ru, https://orcid.org/0000-0002-7119-3925

5 khrebtovart@mail.ru, https://orcid.org/0000-0001-5515-323X

6 george.cirlin@mail.ru, https://orcid.org/0000-0003-0476-3630

\section{Аннотация}

В настоящее время полупроводниковые наноструктуры пониженной размерности на основе соединений III-V групп привлекают все больший интерес исследователей для создания приборов нового поколения. Особенный интерес вызывают комбинации наноструктур разной размерности, например квантовая точка в теле нитевидного нанокристалла. Контроль размеров и расположения таких квантовых точек строго определяются параметрами роста. В результате эффективной релаксации механических напряжений на боковых гранях нитевидных нанокристаллов возможна интеграция гибридных наноструктур с кремниевой технологией. В работе продемонстрирована возможность роста методом молекулярно-пучковой эпитаксии GaP нитевидных нанокристаллов c GaAs квантовыми точками и $\mathrm{AlGaP}$ — c InGaP квантовыми точками на кремниевых подложках. Исследованы физические свойства выбранных нитевидных кристаллов. Эксперименты по росту массивов нитевидных нанокристаллов с квантовыми точками выполнены с помощью установки Riber Compact 21, которая оснащена, кроме ростовой камеры, вакуумно-совмещенной камерой для нанесения золота (камера металлизации). Морфологические свойства полученных наноструктур исследованы методом растровой электронной микроскопии. Оптические свойства наноструктур исследованы методом фотолюминесценции. Результаты исследований морфологических свойств выращенных наноструктур показали, что GaP c GaAs квантовыми точками сформированы преимущественно в направлении $<111>$ в отличие от AlGaP c InGaP квантовыми точками, которые в ряде случаев изменили направление роста. Причиной изменения направления роста нанокристаллов может быть участие индия в ростовом процессе. При достаточном содержании индия в золотой капле-катализаторе, такая смешанная капля может травить фасетки на вершине нитевидного нанокристалла, тем самым спускаясь на бок и изменяя направление роста. Исследования оптических свойств выращенных наноструктур показали, что сигнал фотолюминесценции от InGaP квантовых точек в AlGaP нитевидных нанокристаллах наблюдается при температуре $-263{ }^{\circ} \mathrm{C}$ с максимумом пика около 550 нм. Таким образом, синтезированные наноструктуры перспективны для оптоэлектронных применений, в частности, для создания источников одиночных фотонов.

\section{Ключевые слова}

полупроводники, соединения III-V, нитевидные нанокристаллы, квантовые точки, кремний, морфологические свойства, фотолюминесценция

\section{Благодарности}

Эксперименты по синтезу наноструктур были проведены при поддержке Министерства науки и высшего образования Российской Федерации, проект тематики научных исследований № 2019-1442. Исследования морфологических и оптических свойств выращенных наноструктур были выполнены при поддержке гранта Российского фонда фундаментальных исследований (РФФИ) № 18-02-40006 мега.

Ссылка для цитирования: Резник Р.Р., Котляр К.П., Штром И.В., Самсоненко Ю.Б., Хребтов А.И., Цырлин Г.Э. Синтез методом молекулярно-пучковой эпитаксии и свойства нитевидных нанокристаллов с квантовыми точками на основе соединений III-V групп на поверхности кремния // Научно-технический вестник информационных технологий, механики и оптики. 2021. Т. 21, № 6. С. 866-871 (на англ. яз.). doi: 10.17586/2226-1494-2021-21-6-866-871

\section{Introduction}

III-V nanowires (NWs) and quantum dots (QDs) attract increased interest for the development of novel devices for microelectronics, optoelectronics, analytical biomedicine, emission cathodes, probes for scanning tunnelling microscopy, high-efficiency solar energy converters, etc. [1]. Due to the ability to accumulate for strain in two dimensions [2-4], the NW geometry is ideal for monolithic integration of semiconductor materials with different lattice-mismatched substrates, which is important for achieving high-performance optoelectronic devices based on Si technology. Separate parts of NWs can be formed in different crystal phases, which expand 
the number of possible applications. Therefore III-V NWs with QDs are promising building blocks for future closeto-volume-minimizing devices and scalable bottom-up photonic parts, which can be integrated with a silicon electronic platform $[5,6]$. The diameter, height, and density of such QDs are defined by the NW diameter, the growth time, and the NW density, respectively, and can be chosen more predictable. Due to a very efficient strain relaxation on the free sidewalls, epitaxial growth can be much easier realized in the NW geometry, where a small footprint is dictated by a metal catalyst particle assisting the NW growth via the vapor-liquid-solid (VLS) mechanism [1]. Previously, we have shown the possibility of AlGaAs NWs with GaAs QDs growth [7-13] and InP NWs with InAsP QDs growth [14, 15] using molecular-beam epitaxy (MBE) technology. Nevertheless, expanding the range of materials of the constituents of both NWs and QDs will help to significantly increase the number of applications for such nanostructures.

In this work, we present the possibility of the growth using MBE method of GaP NWs with GaAs QDs and AlGaP NWs with InGaP QDs both on silicon substrates.

\section{Experiment}

MBE growth was performed using a Riber 21 Compact machine equipped with, in addition to the growth chamber, a combined vacuum chamber for the deposition of $\mathrm{Au}$ (metallization chamber). Polished silicon wafers were used as substrates for the growth. The growth of the NWs with QDs was performed in several conceptual stages. On the first stage, after the wafer's surfaces treatment in a 10:1 aqueous solution of HF, the substrates were immediately loaded to the metallization chamber, where they were heated up to the temperature of $850^{\circ} \mathrm{C}$ for $10 \mathrm{~min}$. Then the temperature of the samples was decreased to $550{ }^{\circ} \mathrm{C}$ and $\mathrm{Au}$ deposition was performed with a total thickness of about $0.1 \mathrm{~nm}$ keeping 1 minute at the same temperature to form regular Au droplets on the substrate's surface. After this, the samples were cooled down to the room temperature and transferred to the growth chamber without the violation of ultrahigh-vacuum conditions. Then, to grow the GaP NWs the substrate temperature was increased to the $580{ }^{\circ} \mathrm{C}$, and $\mathrm{Ga}$ and $\mathrm{P}$ sources were opened for 15 minutes. On the next step, Ga and P shutters were closed for 1 minute so that phosphorus was pumped out of the chamber and did not participate in the growth of the QDs. After that, $\mathrm{Ga}$ and As shutters were opened for 7 seconds for GaAs QD formation. Finally, after 1 minute pause for pumping of As, Ga and P shutters were again opened for 5 minutes to form a top of GaP NWs. In case of $\mathrm{AlGaP}$ NWs with InGaP QDs, the growth method was not fundamentally different, but the substrate temperature during the growth was set at $530{ }^{\circ} \mathrm{C}$ due to the specificity of the aluminum and indium atoms migration during the growth. In all cases, the flux of gallium source corresponded to the growth rate of $\mathrm{GaAs}-0.7$ monolayers per second $(\mathrm{ML} / \mathrm{s})$, of $\mathrm{Al}$ source - $0.3 \mathrm{ML} / \mathrm{s}$, and of In source $0.3 \mathrm{ML} / \mathrm{s}$ according to the previous calibrations on a separate GaAs (100) surface. All samples were grown at group V-stabilized conditions. Dynamics observation of reflection high-energy electron diffraction (RHEED) patterns shows pure wurtzite NWs crystallographic phase formed already after 1 minute of growth for all the samples.

The morphological properties of grown experimental samples were studied by scanning electron microscopy (SEM) using Supra 25 Zeiss microscope. Photoluminescence (PL) of the samples was excited with a helium-cadmium (He-Cd) metal-vapor laser with a wavelength of $325 \mathrm{~nm}$. The PL signal was detected using a DK480 Spectral products monochromator and a singlechannel silicon detector using synchronous detection (SRS 510 'Stanford Research Systems'). The measurements were performed at $-263{ }^{\circ} \mathrm{C}$.

\section{Results}

Fig. 1 shows the typical SEM image of GaP NWs array with GaAs QDs grown on $\mathrm{Si}(111)$ substrate. The NWs are formed mainly in the $<111>$ direction, which indicates the epitaxial growth of the nanostructures. We note that the height and diameter of the grown nanostructures is highly inhomogeneous over the surface, which can lead to the difference in the optical properties. The possible reason may be different sizes of the Au particles formed prior to the growth of GaP NWs, and investigation of the optical properties of this array needs additional optimization.

Typical SEM images of AlGaP NWs with InGaP QDs are shown in Fig. 2. Similar to the case of GaP NWs, AlGaP NWs were formed mainly in the $<111>$ direction. It is seen that the average high of grown NWs is $900 \mathrm{~nm}$ and the diameter - $140 \mathrm{~nm}$. It is important to note that some of the NWs began to bend and grow in a different direction. This is due to the usage of indium as a part of quantum dot material. According to [16], with a sufficient content of indium in the gold catalyst droplet, such a mixed droplet can etch the facets at the top of the NWs, thereby descending to the side of the NWs, and change the direction of NWs growth.

A PL study of AlGaP NWs with InGaP QDs grown on $\mathrm{Si}(111)$ substrate showed interesting results (Fig. 3). PL spectrum from this sample is centered at $550 \mathrm{~nm}$, which is bigger than the wavelengths of both AlP and GaP, supporting that the PL signal is attributed to the nanoscale insertion.

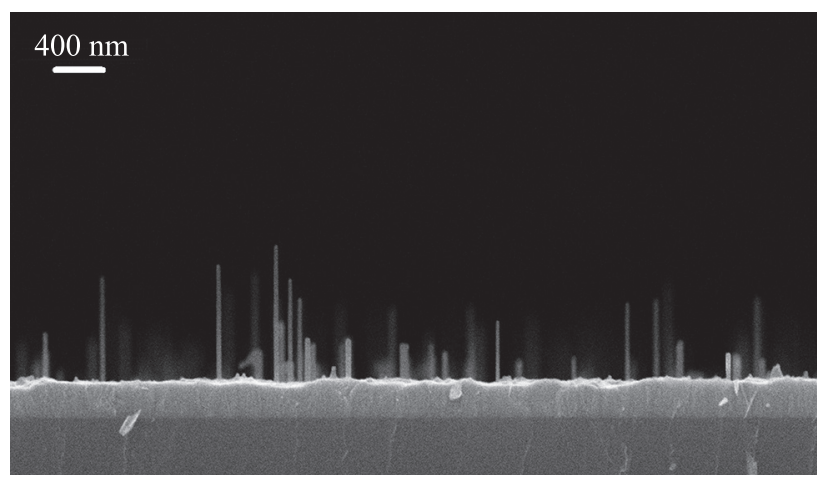

Fig. 1. Typical SEM image of GaP NWs with GaAs QDs grown on $\mathrm{Si}(111)$ substrate 


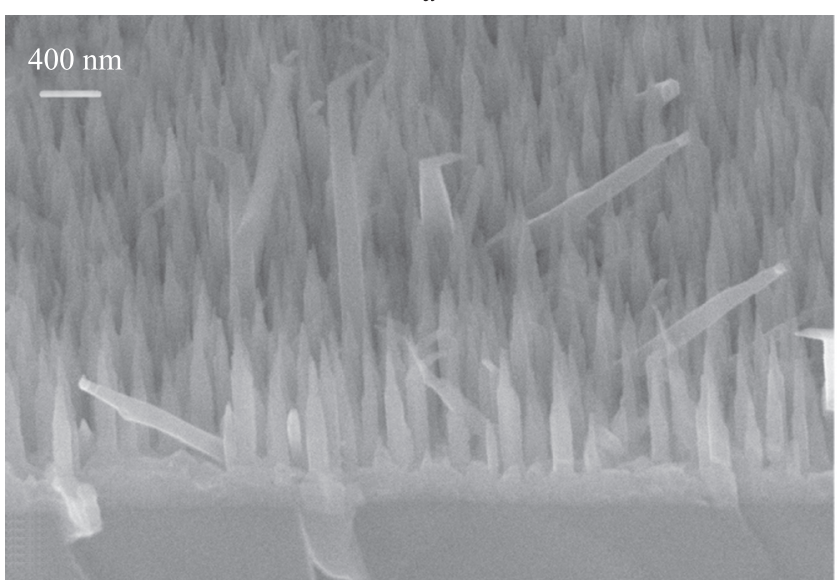

$b$

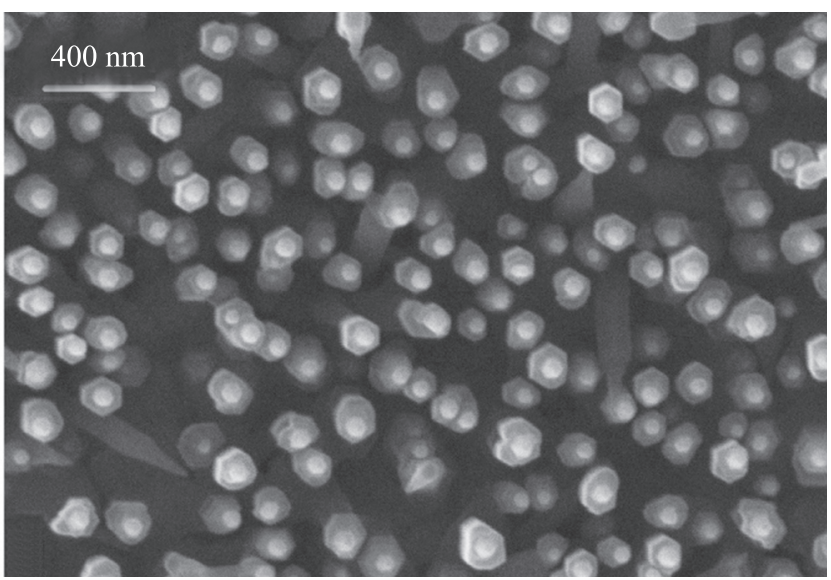

Fig. 2. Typical SEM image of AlGaP NWs with InGaP QDs grown on Si(111) substrate: side view $(a)$; top view $(b)$

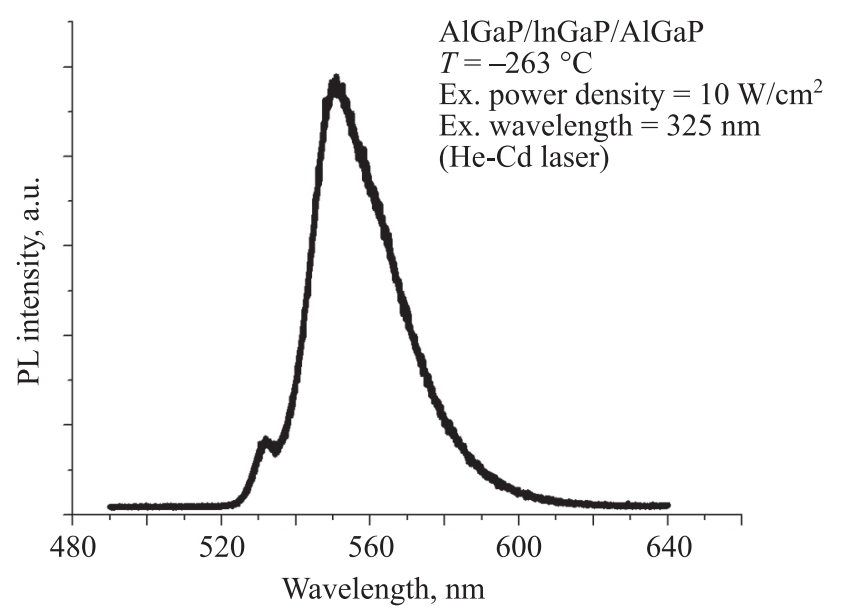

Fig. 3. Typical PL spectrum at $-263^{\circ} \mathrm{C}$ of AlGaP NWs with InGaP QDs grown on $\mathrm{Si}(111)$ substrate

\section{References}

1. Dubrovskii V.G., Cirlin G.E., Ustinov V.M. Semiconductor nanowhiskers: Synthesis, properties, and applications. Semiconductors, 2009, vol. 43, no. 12, pp. 1539-1584. https://doi, org/10.1134/S106378260912001X

2. Glas F. Critical dimensions for the plastic relaxation of strained axial heterostructures in free-standing nanowires. Physical Review B, 2006, vol. 74, no. 12, pp. 121302. https://doi.org/10.1103/ PhysRevB.74.121302

3. Chuang L.C., Moewe M., Chase C., Kobayashi N.P., ChangHasnain C., Crankshaw S. Critical diameter for III-V nanowires grown on lattice-mismatched substrates. Applied Physics Letters, 2007, vol. 90, no. 4, pp. 043115. https://doi.org/10.1063/1.2436655

4. Moewe M., Chuang L.C., Dubrovskii V.G., Chang-Hasnain C. Growth mechanisms and crystallographic structure of InP nanowires on lattice-mismatched substrates. Journal of Applied Physics, 2008, vol. 104, no. 4, pp. 044313. https://doi.org/10.1063/1.2968345

5. Hyun J.K., Zhang S., Lauhon L.J. Nanowire heterostructures. Annual Review of Materials Research, 2013, vol. 43, pp. 451-479. https:// doi.org/10.1146/annurev-matsci-071312-121659

6. Ng K.W., Ko W.S., Tran T-T.D., Chen R., Nazarenko M.V., Lu F., Dubrovskii V.G., Kamp M., Forchel A., Chang-Hasnain C.J. Unconventional growth mechanism for monolithic integration of III-V on silicon. ACS Nano, 2013, vol. 7, no. 1, pp. 100-107. https:// doi.org/10.1021/nn3028166

7. Leandro L., Gunnarsson C.P., Reznik R., Jöns K.D., Shtrom I., Khrebtov A., Kasama T., Zwiller V., Cirlin G., Akopian N. Nanowire

\section{Conclusion}

In conclusion, we have demonstrated the principal growth possibility of GaP nanowires with GaAs quantum dots and AlGaP nanowires with InGaP quantum dots on silicon substrates. The morphological and optical properties of the grown nanostructures were investigated. In particular, it was shown that the PL signal from InGaP QDs in AlGaP NWs is observed at a temperature of $-263{ }^{\circ} \mathrm{C}$ with a peak maximum of around $550 \mathrm{~nm}$. Our work, therefore, opens new prospects for integration of direct bandgap semiconductors with silicon platform for various applications in the fields of silicon photonics and quantum information technology, particularly for singlephoton sources.

\section{Литература}

1. Dubrovskii V.G., Cirlin G.E., Ustinov V.M. Semiconductor nanowhiskers: Synthesis, properties, and applications // Semiconductors. 2009. V. 43. N 12. P. 1539-1584. https://doi. org/10.1134/S106378260912001X

2. Glas F. Critical dimensions for the plastic relaxation of strained axial heterostructures in free-standing nanowires // Physical Review B. 2006. V. 74. N 12. P. 121302 . https://doi.org/10.1103/ PhysRevB.74.121302

3. Chuang L.C., Moewe M., Chase C., Kobayashi N.P., ChangHasnain C., Crankshaw S. Critical diameter for III-V nanowires grown on lattice-mismatched substrates // Applied Physics Letters. 2007. V. 90. N 4. P. 043115. https://doi.org/10.1063/1.2436655

4. Moewe M., Chuang L.C., Dubrovskii V.G., Chang-Hasnain C. Growth mechanisms and crystallographic structure of InP nanowires on lattice-mismatched substrates // Journal of Applied Physics. 2008. V. 104. N 4. P. 044313. https://doi.org/10.1063/1.2968345

5. Hyun J.K., Zhang S., Lauhon L.J. Nanowire heterostructures // Annual Review of Materials Research. 2013. V. 43. P. 451-479. https://doi.org/10.1146/annurev-matsci-071312-121659

6. Ng K.W., Ko W.S., Tran T-T.D., Chen R., Nazarenko M.V., Lu F., Dubrovskii V.G., Kamp M., Forchel A., Chang-Hasnain C.J. Unconventional growth mechanism for monolithic integration of III-V on silicon // ACS Nano. 2013. V. 7. N 1. P. 100-107. https://doi. org/10.1021/nn3028166

7. Leandro L., Gunnarsson C.P., Reznik R., Jöns K.D., Shtrom I., Khrebtov A., Kasama T., Zwiller V., Cirlin G., Akopian N. Nanowire 
quantum dots tuned to atomic resonances. Nano Letters, 2018, vol. 18 , no. 11 , pp. 7217-7221. https://doi.org/10.1021/acs. nanolett.8b03363

8. Leandro L., Reznik R., Clement J.D., Repän J., Reynolds M., Ubyivovk E.V., Shtrom I.V., Cirlin G., Akopian N. Wurtzite AlGaAs nanowires. Scientific Reports, 2020, vol. 10, no. 1, pp. 735. https:// doi.org/10.1038/s41598-020-57563-0

9. Cirlin G.E., Reznik R.R., Shtrom I.V., Khrebtov A.I., Soshnikov I.P., Kukushkin S.A., Leandro L., Kasama T., Akopian N. AlGaAs and $\mathrm{AlGaAs} / \mathrm{GaAs} / \mathrm{AlGaAs}$ nanowires grown by molecular beam epitaxy on silicon substrates. Journal of Physics D: Applied Physics, 2017, vol. 50, no. 48, pp. 484003. https://doi.org/10.1088/1361-6463/ aa9169

10. Cirlin G.E., Reznik R.R., Shtrom I.V., Khrebtov A.I., Samsonenko Yu.B., Kukushkin S.A., Kasama T., Akopian N., Leonardo L. Hybrid GaAs/AlGaAs Nanowire-Quantum dot system for single photon sources. Semiconductors, 2018, vol. 52, no. 4, pp. 462-464. https://doi.org/10.1134/S1063782618040103

11. Cirlin G.E., Shtrom I.V., Reznik R.R., Samsonenko Yu.B., Khrebtov A.I., Bouravleuv A.D., Soshnikov I.P. Hybrid AlGaAs/ GaAs/AlGaAs nanowires with a quantum dot grown by molecular beam epitaxy on silicon. Semiconductors, 2016, vol. 50, no. 11, pp. 1421-1424. https://doi.org/10.1134/S1063782616110257

12. Reznik R.R., Shtrom I.V., Samsonenko Yu.B., Khrebtov A.I., Soshnikov I.P., Cirlin G.E. The dependence of the wavelength on MBE growth parameters of GaAs quantum dot in AlGaAs NWs on Si (111) substrate. Journal of Physics: Conference Series, 2017, vol. 929, no. 1, pp. 012047 . https://doi.org/10.1088/17426596/929/1/012047

13. Leandro L., Hastrup J., Reznik R., Cirlin G., Akopian N. Resonant excitation of nanowire quantum dots. npj Quantum Information, 2020, vol. 6, no. 1, pp. 93. https://doi.org/10.1038/s41534-020-00323-9

14. Reznik R.R., Cirlin G.E., Shtrom I.V., Khrebtov A.I., Soshnikov I.P., Kryzhanovskaya N.V., Moiseev E.I., Zhukov A.E. Coherent growth of InP/InAsP/InP nanowires on a Si (111) surface by molecular-beam epitaxy. Technical Physics Letters, 2018, vol. 44, no. 2, pp. 112-114. https://doi.org/10.1134/S1063785018020116

15. Cirlin G.E., Reznik R.R., Samsonenko Yu.B., Khrebtov A.I., Kotlyar K.P., Ilkiv I.V., Soshnikov I.P., Kirilenko D.A., Kryzhanovskaya N.V. Phosphorus-based nanowires grown by molecular-beam epitaxy on silicon. Semiconductors, 2018, vol. 52, no. 11, pp. 1416-1419. https://doi.org/10.1134/S1063782618110258

16. Wang J., Plissard S.R., Verheijen M.A., Feiner L.-F., Cavalli A., Bakkers E.P. Reversible switching of InP nanowire growth direction by catalyst engineering. Nano Letters, 2013, vol. 13, no. 8, pp. $3802-$ 3806. https://doi.org/10.1021/n1401767b

\section{Authors}

Rodion R. Reznik - PhD, Junior Researcher, ITMO University, Saint Petersburg, 197101, Russian Federation, sc 57035485600, https://orcid. org/0000-0003-1420-7515,moment92@mail.ru

Konstantin P. Kotlyar - Junior Researcher, St. Petersburg State University, Saint Petersburg, 199034, Russian Federation, Sc 57092676600, https://orcid.org/0000-0002-0305-0156, konstantin21kt@ gmail.com

Igor V. Shtrom - PhD, Senior Researcher, St. Petersburg State University, Saint Petersburg, 199034, Russian Federation, Sc 15049790900, https://orcid.org/0000-0001-8912-2570,igorstrohm@, mail.ru

Yuriy B. Samsonenko - Scientific Researcher, Alferov University, Saint Petersburg, 194021, Russian Federation; Researcher, Institute for Analytical Instrumentation of the Russian Academy of Sciences, Saint Petersburg, 190103, Russian Federation, sc 35411251800, https://orcid. org/0000-0002-7119-3925, samsonenko@beam.ioffe.ru

Artem I. Khrebtov - Senior Researcher, Alferov University, Saint Petersburg, 194021, Russian Federation, sc 6602521504, https://orcid. org/0000-0001-5515-323X, khrebtovart@mail.ru quantum dots tuned to atomic resonances // Nano Letters. 2018. V. 18. N 11. P. 7217-7221. https://doi.org/10.1021/acs.nanolett.8b03363

8. Leandro L., Reznik R., Clement J.D., Repän J., Reynolds M., Ubyivovk E.V., Shtrom I.V., Cirlin G., Akopian N. Wurtzite AlGaAs nanowires // Scientific Reports. 2020. V. 10. N 1. P. 735. https://doi. org/10.1038/s41598-020-57563-0

9. Cirlin G.E., Reznik R.R., Shtrom I.V., Khrebtov A.I., Soshnikov I.P., Kukushkin S.A., Leandro L., Kasama T., Akopian N. AlGaAs and $\mathrm{AlGaAs} / \mathrm{GaAs} / \mathrm{AlGaAs}$ nanowires grown by molecular beam epitaxy on silicon substrates // Journal of Physics D: Applied Physics. 2017. V. 50. N 48. P. 484003. https://doi.org/10.1088/1361-6463/aa9169

10. Cirlin G.E., Reznik R.R., Shtrom I.V., Khrebtov A.I., Samsonenko Yu.B., Kukushkin S.A., Kasama T., Akopian N., Leonardo L. Hybrid GaAs/AlGaAs Nanowire-Quantum dot system for single photon sources // Semiconductors. 2018. V. 52. N 4. P. $462-$ 464. https://doi.org/10.1134/S1063782618040103

11. Cirlin G.E., Shtrom I.V., Reznik R.R., Samsonenko Yu.B., Khrebtov A.I., Bouravleuv A.D., Soshnikov I.P. Hybrid AlGaAs/ GaAs/AlGaAs nanowires with a quantum dot grown by molecular beam epitaxy on silicon // Semiconductors. 2016. V. 50. N 11. P. 1421-1424. https://doi.org/10.1134/S1063782616110257

12. Reznik R.R., Shtrom I.V., Samsonenko Yu.B., Khrebtov A.I., Soshnikov I.P., Cirlin G.E. The dependence of the wavelength on MBE growth parameters of GaAs quantum dot in AlGaAs NWs on Si (111) substrate // Journal of Physics: Conference Series. 2017. V. 929. N 1. P. 012047. https://doi.org/10.1088/17426596/929/1/012047

13. Leandro L., Hastrup J., Reznik R., Cirlin G., Akopian N. Resonant excitation of nanowire quantum dots // npj Quantum Information. 2020. V. 6. N 1. P. 93. https://doi.org/10.1038/s41534-020-00323-9

14. Reznik R.R., Cirlin G.E., Shtrom I.V., Khrebtov A.I., Soshnikov I.P., Kryzhanovskaya N.V., Moiseev E.I., Zhukov A.E. Coherent growth of InP/InAsP/InP nanowires on a Si (111) surface by molecular-beam epitaxy // Technical Physics Letters. 2018. V. 44. N 2. P. 112-114. https://doi.org/10.1134/S1063785018020116

15. Cirlin G.E., Reznik R.R., Samsonenko Yu.B., Khrebtov A.I., Kotlyar K.P., Ilkiv I.V., Soshnikov I.P., Kirilenko D.A., Kryzhanovskaya N.V. Phosphorus-based nanowires grown by molecular-beam epitaxy on silicon // Semiconductors. 2018. V. 52. N 11. P. 1416-1419. https://doi.org/10.1134/S1063782618110258

16. Wang J., Plissard S.R., Verheijen M.A., Feiner L.-F., Cavalli A., Bakkers E.P. Reversible switching of InP nanowire growth direction by catalyst engineering // Nano Letters. 2013. V. 13. N 8. P. 38023806. https://doi.org/10.1021/n1401767b

\section{Авторы}

Резник Родион Романович - кандидат физико-математических наук, младший научный сотрудник, Университет ИТМО, СанктПетербург, 197101, Российская Федерация, sc 57035485600, https:// orcid.org/0000-0003-1420-7515, moment92@mail.ru

Котляр Константин Павлович - младший научный сотрудник, Санкт-Петербургский государственный университет, СанктПетербург, 199034, Российская Федерация, sc 57092676600, https:// orcid.org/0000-0002-0305-0156, konstantin21kt@gmail.com

Штром Игорь Викторович - кандидат физико-математических наук, старший научный сотрудник, Санкт-Петербургский государственный университет, Санкт-Петербург, 199034, Российская Федерация, sc 15049790900, https://orcid.org/0000-0001-8912-2570, igorstrohm@mail.ru

Самсоненко Юрий Борисович - научный сотрудник, СанктПетербургский национально-исследовательский академический университет имени Ж.И. Алфёрова РАН, Санкт-Петербург, 194021, Российская Федерация; старший научный сотрудник, Институт аналитического приборостроения РАН, Санкт-Петербург, 190103, Российская Федерация, Sc 35411251800, https://orcid.org/0000-00027119-3925, samsonenko@beam.ioffe.ru

Хребтов Артём Игоревич - старший научный сотрудник, СанктПетербургский национально-исследовательский академический университет имени Ж.И. Алфёрова РАН, Санкт-Петербург, 194021, Российская Федерация, sc 6602521504, https://orcid.org/0000-00015515-323X,khrebtovart@mail.ru 
George E. Cirlin - D.Sc., Head of Laboratory, Alferov University, Saint Petersburg, 194021, Russian Federation; Chief Researcher, Institute for Analytical Instrumentation of the Russian Academy of Sciences, Saint Petersburg, 190103, Russian Federation; Leading Researcher, ITMO University, Saint Petersburg, 197101, Russian Federation, sc 7005945087, https://orcid.org/0000-0003-0476-3630,george.cirlin@mail.ru

Received 08.09.2021

Approved after reviewing 05.10.2021

Accepted 30.10.2021
Цырлин Георгий Эрнстович - доктор физико-математических наук, заведующий лабораторией, Санкт-Петербургский национально-исследовательский академический университет имени Ж.И. Алфёрова РАН, Санкт-Петербург, 194021, Российская Федерация; главный научный сотрудник, Институт аналитического приборостроения РАН, Санкт-Петербург, 190103, Российская Федерация; ведущий научный сотрудник, Университет ИТМО, Санкт-Петербург, 197101 Российская Федерация, sc 7005945087, https://orcid.org/0000-00030476-3630, george.cirlin@mail.ru

Статья поступила в редакиию 08.09.2021

Одобрена после реиензирования 05.10.2021

Принята к печати 30.10.2021

Работа доступна по лицензии

Creative Commons

«Attribution-NonCommercial» 